\title{
Sense of belonging and social identity on the settlement intentions of rural-urban migrants: evidence from China
}

\author{
Zhen Liu ${ }^{1}$ Yujie Zhang ${ }^{2}$ Yuan Zheng ${ }^{3}$ Jing Lan $^{4^{*}}$ Gengrui Zhang $^{1}$ \\ ${ }^{1}$ School of Business, Nanjing Normal University, Nanjing, China. \\ ${ }^{2}$ Honor College, Nanjing Normal University, Nanjing, China. \\ ${ }^{3}$ United Nations Development Programme in China, Beijing, China. \\ ${ }^{4}$ College of Public Administration, Nanjing Agricultural University, No. 1 Weigang, 210095, Nanjing, China. E-mail: lanjinge@yahoo.com. \\ "Corresponding Author.
}

ABSTRACT: Drawing upon data from the China Labor-force Dynamics Survey (CLDS) of 2012 and 2014, this paper uses the panel binary choice model to examine the determinants of the settlement intentions of rural-urban migrants. Results showed that both a sense of belonging and social identity play important roles in determining rural-urban migrants'settlement decisions. Besides these, wage, education, and health also affect the willingness of migrant workers to settle in a given area. Therefore, to promote urbanization, policy-makers should pay attention to the subjective demands of rural-urban migrants. We suggested that decision-and policy-makers help such migrants improve their social networks and eliminate identity discrimination, so as to encourage their willingness to settle in cities.

Key words: sense of belonging, social identity, settlement intention, rural-urban migrants, China.

$O$ efeito do senso e identidade social nas intenções de assentamento de migrantes rurais-urbanos: evidências da China

RESUMO: Com base nos dados do Laboratório de Dinâmica da Força de Trabalho da China (CLDS) de 2012 e 2014, este artigo usa o modelo de escolha binária do painel para examinar os determinantes das intenções de assentamento de migrantes rurais-urbanos. Os resultados mostram que tanto o senso de pertencimento, quanto a identidade social, desempenham papéis importantes na determinação das decisões de assentamentos de migrantes rurais-urbanos. Além destes, salário, educação e saúde também afetam a disposição dos trabalhadores migrantes de se estabelecerem em uma determinada área. Portanto, a fim de promover a urbanização, os formuladores de políticas devem prestar atenção às demandas subjetivas dos migrantes rurais-urbanos. Sugerimos que autoridades e formuladores de politicas públicas ajudem esses migrantes a melhorar sua rede social e a eliminar a discriminação de identidade, de modo a incentivar sua disposição de se estabelecer nas cidades.

Palavras-chave: senso de pertencer, identidade social, intenção de liquidação, migrantes rurais-urbanos, China.

\section{INTRODUCTION}

With the acceleration of urbanization in China, rural migrant workers - the so-called "floating population" - have increasingly constituted a major proportion of new comers in urban areas. According to the 2016 Migrant Workers Detection Survey Report by the National Bureau of Statistics of China, the total number of migrant workers nationwide reached 280 million as of the end of 2016, having increased by 4.24 million over the previous year. They have made significant contribution to China's economic development and modernization. However, due to the Household Registration System which prevents migrant workers from enjoying welfare benefits in urban areas, the rural-urban segmentation still widely exists. Promotion of smooth and inclusive urbanization in the development of modern Chinese society has become a main concern for the future.
In recent years, the government has attached great importance to the challenge facing rural migrant workers and has devised corresponding policies to both increase employment and promoted entrepreneurship amongst migrant workers and effectively safeguard their rights through labor protection laws. However, the living condition of migrant workers is still largely determined by where they relocate. The choice of destination city is related to many factors. Although, the most important incentives for migration are the availability of employment opportunities, and the prospect of an improved livelihood, subjective feelings (cognitive and affective) also contributed significantly to migration decisions (LIU et al. 2017). Previous studies (ZHU, 2007; ZHU and CHEN, 2010; FAN, 2011) have investigated the relationship between migrants' sense of belonging and the willingness of rural-urban migrants to settle. 
All results demonstrated that affective evaluations of both neighborhood and society are highly relevant to migrants' mobility intensity. Another knowledge gap is seen in the measurement of various subjective factors that play in the intention to settle in the destination city. Previous studies mostly used descriptive statistics and logistical regression to study social-economic variables; however, few, if any, studies considered the influence of social identity on their willingness to settle. One of the more pervasive assumptions in the social sciences suggested that peoples' attitudes and actions (migrants' intentions in this case) are shaped by the communities in which they live. This is because their social identity offers them easy and reliable access to information and resources through social ties and networks (LEE et al. 1994). To close the knowledge gaps, this study aimed to take mutual subjective facto into account on migrants' settlement intention and also develop a preliminary guide regarding the importance of the two spheres of subjective factors (sense of belonging and social identity) influencing the decision-making process of migrants.

This study uses national sample survey data from the China Labor-force Dynamics Survey (CLDS), conducted by the Center for Social Surveys in 2012 and 2014. After analyzing the contingency tables, we reported that the willingness of ruralurban migrants to settle in cities has been increasing year by year. Therefore, after taking the hysteresis effect into consideration, this paper uses the panel binary choice model to measure the direct impact of migrants' sense of belonging, social identity, economic characteristics, and demographic characteristics on their willingness to settle, to provide an empirical basis for policy making.

\section{Literature review}

There are many factors which affect a workforce's willingness to settle. Many scholars believe that the intentions of labor migrants are to obtain increased future returns (SCHULTZ, 1961; WU \& ZHANG, 2015) and avoid the risks of agricultural production, to secure a more stable source of long-term income (STARK, 1988). Todaro (1969) established a new "rural-urban" labor migration model by introducing the concept of "expected income" in towns. On this basis, other economists continued to conduct research on the issue of labor migration, but most applied a dichotomy to their studies (SHIELDS, G.M \& SHIELDS, M.P, 1989). BELGIOJOSO (2016) believed that settlement intention is related to an attachment to the inflow area.
CHISWICK \& MILLER (1995) showed that the local dialect level of a labor force affected their income and social integration level, and thus had an impact on their willingness to settle in a given area. ROBERT \& LUCAS (2004) and ETTE et al. (2015) reported that occupational skills are the most important factor for successful migration. Other demographic variables, such as age, gender, income, educational level, and marital status also increase the likelihood of settlement (TANG \& FENG, 2015; CHEN \& LIU, 2016; YOU et al., 2018; HAO \& TANG, 2015).

Although, the nature and definition of urban-rural migration is different in Latin America, Africa, and Asia (IDRC, 1977; NELSON, 1976), the research team thinks that results of Chinese and foreign studies on the settlement intention of labor forces have much in common. In the research on the flow of rural-urban migrants in China, early scholars tended to study the influence of the household registration system on rural-urban migrants' city integration and urban settlement intentions. It was discovered that the household registration system was resulting in migrant workers suffering longterm discrimination, a situation that was (and still is) affecting their settlement decisions (ZHAI et al., 2009). Once the hukou barrier is eliminated, ruralurban migrants would likely choose to permanently live in cities (CHEN \& LIU, 2016). However, ZHU (2007) argued that even without the impediment of the household registration system, the "floating population" would still choose to work in different places according to the situation of their families, which was found in a survey of such populations in Fujian province. The distinctive family and career lifecycle stages of migrant workers affect their settlement intentions (TANG \& FENG, 2015). Scholars have also shown that other objective factors increase the probability of rural-urban migrants residing in cities. Education, age, income, employment status, and occupation type have a significant impact on their settlement intentions (LIU et al., 2018). REN and MIN (2006) believed that rural-urban migrants who have worked for a long time and have purchased housing in cities are more likely to settle in them. HUANG (2008) reported that age, income, housing, and pension security of migrants have a significant impact on their settlement decisions and intentions. It has also been reported that the proportion of migrant workers willing to settle down in cities has increased, especially for those who are female, unmarried, or highly-educated (CHEN, 2008). New generations of rural-urban migrants who are younger and more educated are more willing to settle in cities; different 
family patterns also affect their choice of settlement (FAN, 2011). Moreover, the characteristics of cities have significant effects on the settlement intention of migrant workers (LIU et al., 2018).

Due to the existence of dual societies and the substantial gap between urban and rural areas in China, when rural-urban migrants flow into cities, they inevitably face the problem of acculturation (SCHWARTZ, et al., 2006). Non-institutional factors have increasingly made it difficult for new generations of rural-urban migrants to stay in cities (XIAO \& DENG, 2015), resulting in scholars beginning to pay attention to the subjective appeals of rural laborers. WANG (2013), using questionnaire surveys issued throughout 12 Chinese cities, reported that rural-urban migrants' sense of belonging played a key role in their settlement intentions. Factors such as education, marital status, job skills, and interactions with locals were found to indirectly influence the desire to settle by affecting their sense of belonging. Positive professional identity can provide moral incentive for migrant workers. This not only helps them make better career choices that will benefit their future livelihoods (MALANCHUK et al., 2010), but also provides them with a sense of psychological security (CRAMER, 2004; FLYNN, 2017), thereby making them better integrated into cities. ZHANG (2017) showed that social support makes rural-urban migrants stay in cities through the mediating effect of psychological well-being.

Many scholars focus on the impact of objective factors such as housing prices, wages, and how household registration affects rural-urban migrants' settlement decisions (LIU et al., 2014). With an increase in migrant worker wages and improvements to their living conditions, objective factors such as social capital no longer have a significant impact on their settlement decisions (HUANG, 2008). A few scholars have considered the effect of the subjective aspects determining their intention to settle in cities. By incorporating both cognitive and affective evaluations, DU \& LI (2012) demonstrated that migrants' stay-leave intention is more of an affective than a cognitive choice. Based on fieldwork in SHANGHAI \& ANHUI, MOHABIR et al. (2017) examined how characteristics (age, gender, etc.) and sense of belonging affected the choice of rural migrants to stay or return. ZHANG et al. (2017) researched how the determinants of rural-urban migration differ across different ethnic backgrounds, using survey data from three cities in Gansu province in northwest China. Using a combination of data from 12,807 rural-urban migrants across eight cities in China, HUANG et al. (2018) investigated the interconnection between social networks and settlement intentions; the social ties of migrants have heterogenous effects on rural-urban migrants' intention among the different dimensions affecting it. In previous literature concerning the influence of subjective factors on the willingness of migrant workers to settle, some scholars used questionnaire surveys to study certain cities and provinces. In addition, most studies used cross-sectional data, which neglects the effects of time and hysteresis on their findings.

This study contributes to existing literature in three ways. First, the paper fills a gap in the literature by responding to questions of rural-urban migration and settlement through the lens of subjective aspects, particularly rural-urban migrants' sense of belonging and social identity, which is seldom reported in existing studies. As a metric for subjective appeal, this approach examines their impact on migrants' settlement intentions and decisions more effectively, thereby providing a reference for promoting urbanization from a subjective perspective. Second, by using a panel binary choice model, this study aimed to test the influence of the sense of belonging and social identity on rural-urban migrants' settlement intentions. The value of this approach is in the overall weighted average of the various multilevel variables. Complex variables give a more accurate answer to the question concerning what extent subjectivities, both belonging and identity, explain rural migrants' intentions to stay in or leave a host city. Finally, this study uses household level panel data derived from the China Labor-force Dynamics Survey in 2012 and 2014, which has strong comparability and reduces the hysteresis effect for various factors. It is; therefore, critical that there be different effects on the factors motivating rural-urban migrants, due to evolving characteristics and trends. The survey, which covers 21 provinces and cities across China, attempted to provide a more comprehensive analysis of the subjective determinants affecting rural migrants' intention to settle in their target cities.

\section{Data}

Data sources

The data for this study was collected from the China Labor-force Dynamics Survey (CLDS), conducted by the Center for Social Survey in 2012 and 2014. The first survey began in 2012 and covered 21 provinces and cities in China, save Hong Kong, Macao, Taiwan, Tibet, and Hainan. The survey targeted laborers aged 15-64 as sample households and used a 
multi-stage, multi-level probability sampling method. Household surveys began by dividing provinces into "collection regions" and selecting some of these collection regions (first stage). The selected collection regions were then divided into blocks according to geographical coverage, and blocks were chosen from within each selected collection region (second stage). Next, dwellings were listed within each selected block, and some of these dwellings were randomly selected (third stage). This method makes it unnecessary to create a list of every dwelling in the region and necessary only for selected blocks. In remote areas, an additional stage of clustering was applied, to reduce travel requirements. This sampling strategy helped to complete the survey at a low cost, an approach that is usually more accurate than cluster sampling the same size sample.

This paper studied the treatment effect on settlement intentions, induced by the sense of belonging and social identity of rural-urban migrants in 2012 and 2014. Therefore, only households with rural hukous (household registration), but whom are working in a city, were eligible for the study. Moreover, to capture more accurate and dynamic information, a balanced panel data processing method was used, while a total of 244 valid samples were obtained after a follow-up survey by removing data that did not meet the criteria.

\section{Definition of variables used for settlement intention analysis}

In this study, rural-urban migrants' settlement intention was used as the dependent variable. In the questionnaire, the population with rural household registrations currently residing in cities was defined as rural-urban migrants; the possibility of their staying in such cities was reflected by asking them whether they "may settle in the future". The answers, which are "unclear", "impossible", and "less likely", were defined as 0 , that is, they have no clear settlement intention. The answers "very likely" and "more likely" were defined as 1, that is, they have clear settlement intention.

Because the dependent variables studied in this paper are dichotomy variables, which are "willing to settle in cities" and "unwilling to settle in cities", this study used a panel binary choice model to analyze such problems. The model is as follows:

$\operatorname{Pr}\left(\right.$ set $\left._{i t}\right)=\alpha+\beta 1 w 1 i_{, t}+\beta_{2} w 2_{i, t}+\beta_{3} X_{i, t}+\varepsilon_{i, t}$

where $\operatorname{set}_{i, t}$ is the settlement intention and $\operatorname{set}_{i, t}=1$ indicates that rural-urban migrant $i$ has the intention to settle in a city in year $\mathrm{t}$, whereas $\operatorname{set}_{i, t}=0$ indicates the opposite situation. $w 1$ represents rural-urban migrants' sense of belonging, $w 2$ represents their social identity, and $X$ indicates the control variable (including basic pension insurance, health status, housing supply, religious beliefs, technical training, gender, age, education level, and income). $\beta$ represents the corresponding coefficient vector and $\varepsilon$ is the error term.

In view of previous studies and the feasibility of index quantification, this paper selected the sense of belonging and social identity of ruralurban migrants as core independent variables and added variables such as a population's social characteristics and economic factors to study settlement intentions. All these variables warrant a brief explanation (see Table 1).

\section{RESULTS}

\section{Analysis of the contingency tables}

The influence of sense of belonging and social identity on settlement intention

PALMER et al. (2011) and CHEN and LIU (2016) believed that social networking plays an important role in migrant workers' lives in cities. Moreover, the expansion of interpersonal circles not only helps rural-urban migrants build their social networks in cities, but it can also significantly increase their sense of belonging (WANG, 2013; CHEN and LIU, 2016; SHEN and LIU, 2016). Therefore, this study selected the number of friends and relatives of these migrants as a measure of their sense of belonging (KHOO, 2010). Specifically, we chose questions such as "How many relatives are closely related to the respondent from whom they can receive support and help?" to include in the questionnaire and to be the secondary indicator of a given migrant's sense of belonging. Because these variables are considered equally important, all index weights used the method of "average weight", that is, the weight of each secondary indicator is the same.

Table 2 shows that when the variables "support" and "worry" equal 2 and 3 respectively, rural-urban migrants have the strongest willingness to settle in cities. When the variable $\mathrm{w} 1$ is between 2 and 4 , they are more likely to stay in their city, which means that there is a correlation between their sense of belonging and their intention to settle.

While existing scholarship has documented sense of belonging, little, if any, attention has been paid to social identity, which is also considered a key factor for rural-urban migrants in this study. The consideration of social identity makes a large contribution in cases where subjective evaluations of 
Table 1 - Variable description and statistical description.

\begin{tabular}{|c|c|c|c|}
\hline Variables & Description & Mean & SE \\
\hline Settlement & Settlement intention (likely, very likely $=1$, otherwise 0 ) & 0.299 & 0.459 \\
\hline Support & Number of supporters $(16$ or above $=5 ; 11-15=4 ; 6-10=3 ; 1-5=2 ;$ none $=1)$ & 2.32 & 1.00 \\
\hline Worry & $\begin{array}{l}\text { Number of people who can listen to their worries }(9 \text { and above }=5 ; 6-8=4 ; 4-6=3 ; 1-3=2 ; \\
\text { none }=1)\end{array}$ & 2.22 & 0.938 \\
\hline Discussion & $\begin{array}{l}\text { Number of people who can discuss issues with them }(9 \text { and above }=5 ; 6-8=4 ; 4-6=3 ; 1-3=2 \\
\qquad ; \text { none }=1)\end{array}$ & 2.147 & 0.907 \\
\hline Familiar & $\begin{array}{c}\text { Familiarity with others }(\text { Very familiar }=5 \text {; familiar }=4 \text {; general }=3 \text {; not familiar with }=2 \text {; very } \\
\text { unfamiliar }=1)\end{array}$ & 3.057 & 1.053 \\
\hline Trust & $\begin{array}{c}\text { Degree of trust in others }(\text { Very trusting }=5 ; \text { trusting }=4 ; \text { generally trusting }=3 ; \text { less trusting }= \\
2 ; \text { very untrusting }=1)\end{array}$ & 3.184 & 0.756 \\
\hline Help & $\begin{array}{l}\text { Mutual help frequency with others }(\text { Very much }=5 ; \text { much }=4 \text {; generally helpful }=3 ; \text { less }=2 \text {; } \\
\text { very few }=1)\end{array}$ & 2.611 & 1.062 \\
\hline w1 & Sense of belonging $(w 1=($ support + worry + discussion + familiar + trust + help $) / 6)$ & 2.447 & 0.672 \\
\hline Level & $\begin{array}{l}\text { Self-assessment of social level (Social class rises sequentially from } 1-10: 10-9=5 ; 8-7=4 ; 6- \\
\qquad 5=3 ; 4-3=2 ; 2-1=1 \text { ) }\end{array}$ & 2.254 & 0.842 \\
\hline $\begin{array}{l}\text { Respect } \\
\text { Lend }\end{array}$ & $\begin{array}{l}\text { Satisfaction with being respected (Very satisfied }=5 \text {; a little satisfied }=4 \text {; General }=3 \text {; not } \\
\qquad \text { satisfied }=2 \text {; very dissatisfied }=1) \\
\text { The number of people who can lend money to them }(9 \text { and above }=5 ; 6-8=4 ; 4-6=3 ; 1-3=2 \\
\qquad \text { none }=1)\end{array}$ & $\begin{array}{l}3.485 \\
2.089\end{array}$ & $\begin{array}{l}0.732 \\
1.057\end{array}$ \\
\hline w2 & Social identity $(\mathrm{w} 2=($ level + respect + lend $) / 3)$ & 2.834 & 0.643 \\
\hline Insurance & If they have a basic pension insurance $(y e s=1 ; n o=0)$ & 0.169 & 0.375 \\
\hline Health & $\begin{array}{c}\text { Physical condition }(\text { very healthy }=5 \text {; healthy }=4 \text {; generally healthy }=3 \text {; relatively unhealthy }= \\
2 \text {; very unhealthy }=1)\end{array}$ & 3.758 & 0.881 \\
\hline Fund & If they have a housing provident fund $(\mathrm{yes}=1 ; \mathrm{no}=0)$ & 0.140 & 0.348 \\
\hline Religion & Religion $=1$, no religion $=0$ & 0.115 & 0.319 \\
\hline Training & Have they ever attended technical training $(y e s=1 ;$ no $=0)$ & 0.209 & 0.407 \\
\hline Gender & Female $=1$, male $=0$ & 0.475 & 0.500 \\
\hline Age & Age of rural-urban migrants (years) & 38.230 & 10.194 \\
\hline Education & $\begin{array}{c}\text { Doctor }=7 ; \text { Master }=6 ; \text { Undergraduate }=5 ; \text { College }=4 ; \text { High school } / \text { secondary school=3; Junior } \\
\text { high school }=2 ; \text { Primary school }=1\end{array}$ & 2.269 & 0.961 \\
\hline Wage & Continuous variable $(10,000$ yuan $)$ & 3.527 & 2.947 \\
\hline
\end{tabular}

Notes: 'SE' is short for standard error.

migrants' decision-making processes are involved. The concept of social identity also refers to social networking, which is a subjective feeling upon which identity depends, not only in terms of the subjective feelings of rural-urban migrants toward their urban communities, but also regards whether their communities treat them as locals (ASHFORTH $\&$ MAEL, 1989). Therefore, this study attempted to measure "what level the respondent thinks he or she is currently on" as their subjective feeling, and "how much respect from others the respondent is receiving at work". To make the measurement of social identity reflect actual conditions, this study considered "how many people are lending the respondent money" as the degree of recognition by others, since a lending relationship is usually considered a socially acceptable behavior, especially within Chinese social culture. These three variables together form a social identity. We used a weighted average approach to obtain its value.

Table 3 indicated that when the "level" variable equals 2 and 3 and the "support" variable equals 3 and 4, migrants' intention to settle in cities is stronger. In general, the higher the social identity, stronger is the willingness of rural-urban migrants to settle in cities. 
Table 2 - Statistical analysis of the sense of belonging and settlement intention (\%).

\begin{tabular}{|c|c|c|c|c|c|c|c|c|c|c|c|}
\hline \multirow[b]{2}{*}{ Support } & \multicolumn{2}{|c|}{$\begin{array}{l}\text { Settlement } \\
\text { intention }\end{array}$} & \multirow[b]{2}{*}{ Worry } & \multicolumn{2}{|c|}{$\begin{array}{l}\text { Settlement } \\
\text { intention }\end{array}$} & \multirow[b]{2}{*}{ Discussion } & \multicolumn{2}{|c|}{ Settlement intention } & & & \\
\hline & 2012 & 2014 & & 2012 & 2014 & & 2012 & 2014 & & & \\
\hline 1 & 0 & 15.91 & 1 & 17.24 & 15.91 & 1 & 6.90 & 18.18 & & & \\
\hline 2 & 41.38 & 43.18 & 2 & 51.72 & 40.91 & 2 & 65.52 & 47.73 & & & \\
\hline 3 & 31.03 & 31.82 & 3 & 20.69 & 31.82 & 3 & 13.79 & 20.45 & & & \\
\hline 4 & 3.45 & 4.55 & 4 & 3.45 & 0 & 4 & 10.34 & 2.27 & & & \\
\hline 5 & 24.14 & 4.55 & 5 & 6.90 & 11.36 & 5 & 3.45 & 11.36 & & & \\
\hline Familiar & & & Trust & & & Help & & & w1 & & \\
\hline 1 & 3.45 & 4.55 & 1 & 0 & 0 & 1 & 13.79 & 15.91 & $<=1$ & 0 & 0 \\
\hline 2 & 24.14 & 18.18 & 2 & 17.24 & 4.55 & 2 & 31.03 & 27.27 & $1-2$ & 3.45 & 13.64 \\
\hline 3 & 34.48 & 36.36 & 3 & 55.17 & 56.82 & 3 & 34.48 & 25.00 & $2-3$ & 68.97 & 45.45 \\
\hline 4 & 13.79 & 27.27 & 4 & 20.69 & 29.55 & 4 & 13.79 & 20.45 & $3-4$ & 24.14 & 36.36 \\
\hline 5 & 24.14 & 13.64 & 5 & 6.90 & 9.09 & 5 & 6.90 & 11.36 & $>=4$ & 3.45 & 4.55 \\
\hline
\end{tabular}

The influence of control variables on settlement intention

WANG (2013) believed that a sound social security system can strengthen the willingness of ruralurban migrants to settle. We thus wanted to find out "whether the respondent currently has basic pension insurance for enterprise employees" and "how the respondent personally assessed their body condition". We used these questions to gather data on the social security system. Some scholars believed that with the gradual improvement of housing conditions, the chances of migrant workers staying in cities will increase (HUANG, 2008). Therefore, we included "whether the respondent currently has a housing provident fund" as an indicator of improvements to housing conditions.

Many studies have shown that people who believe in non-evangelistic religions have a stronger sense of belonging. This paper thus uses "religion" as a controlling variable. Moreover, some scholars believe that migrant workers with professional skills are more likely to settle in cities than low-skilled migrant workers (WANG, 2013). Thus, "whether the respondent has participated in at least five days of professional technical training" was introduced as a control variable. Some common socioeconomic demographic variables, such as gender, age, education, and wage are also considered in this study. Table 4 reported that social security, such as basic pension insurance and provident housing funds, skills training, and education, have no obvious impact on the settlement intentions of rural-urban migrants, which is contrary to other literature. Concerning demographic characteristics, women were more likely to stay in cities in 2012, while in 2014 the proportion of men who were willing to settle was higher and exceeded that of women. This indicated that the effect of gender on settlement intention is not altogether clear. 26 to 35-year-old rural-urban migrants have the strongest willingness to settle. With the change of age, settlement intentions presented an

Table 3 - Statistical analysis of social identity and settlement intention (\%).

\begin{tabular}{|c|c|c|c|c|c|c|c|c|c|c|c|}
\hline \multicolumn{4}{|c|}{$\begin{array}{l}\text { Settlement } \\
\text { Intention }\end{array}$} & \multicolumn{2}{|c|}{$\begin{array}{l}\text { Settlement } \\
\text { Intention }\end{array}$} & \multicolumn{3}{|c|}{$\begin{array}{l}\text { Settlement } \\
\text { Intention }\end{array}$} & \multicolumn{3}{|c|}{ Settlement Intention } \\
\hline Level & 2012 & 2014 & Respect & 2012 & 2014 & Lend & 2012 & 2014 & w2 & 2012 & 2014 \\
\hline 1 & 27.59 & 11.36 & 1 & 0 & 4.65 & 1 & 31.03 & 27.27 & $<=1$ & 0 & 0 \\
\hline 2 & 34.48 & 27.27 & 2 & 3.45 & 6.98 & 2 & 41.38 & 27.27 & $1-2$ & 0 & 6.82 \\
\hline 3 & 37.93 & 52.27 & 3 & 37.93 & 30.23 & 3 & 6.90 & 29.55 & $2-3$ & 37.93 & 22.73 \\
\hline 4 & 0 & 9.09 & 4 & 51.72 & 46.51 & 4 & 10.34 & 4.55 & $3-4$ & 62.07 & 56.82 \\
\hline 5 & 0 & 0 & 5 & 6.90 & 11.63 & 5 & 10.34 & 11.36 & $>=4$ & 0 & 13.64 \\
\hline
\end{tabular}

Ciência Rural, v.49, n.8, 2019. 
Table 4 - Statistical analysis of control variables and settlement intention (\%).

\begin{tabular}{|c|c|c|c|c|c|c|c|c|}
\hline \multirow[b]{2}{*}{ Insurance } & \multicolumn{2}{|c|}{$\begin{array}{l}\text { Settlement } \\
\text { Intention }\end{array}$} & \multicolumn{4}{|c|}{$\begin{array}{l}\text { Settlement } \\
\text { Intention }\end{array}$} & \multicolumn{2}{|c|}{ Settlement Intention } \\
\hline & 2012 & 2014 & Fund & 2012 & 2014 & Religion & 2012 & 2014 \\
\hline No & 72.41 & 90.70 & No & 89.66 & 86.05 & No & 79.31 & 93.18 \\
\hline Yes & 27.59 & 9.30 & Yes & 10.34 & 13.95 & Yes & 20.69 & 6.82 \\
\hline Training & & & Gender & & & Age & & \\
\hline No & 72.41 & 79.55 & Male & 34.48 & 54.55 & $18-25$ & 6.90 & 4.55 \\
\hline \multirow[t]{4}{*}{ Yes } & 27.59 & 20.45 & Female & 65.52 & 45.45 & $26-35$ & 58.62 & 36.36 \\
\hline & & & & & & $36-45$ & 20.69 & 34.09 \\
\hline & & & & & & $46-55$ & 10.34 & 15.91 \\
\hline & & & & & & 56 and above & 3.45 & 9.09 \\
\hline Wage $(10000 \mathrm{CNY})$ & & & Health & & & Education & & \\
\hline 1.5 and below & 25.00 & 5.56 & 1 & 3.45 & 2.27 & 1 & 3.85 & 20.45 \\
\hline $1.5-2.5$ & 25.00 & 25.00 & 2 & 6.90 & 9.09 & 2 & 61.54 & 36.36 \\
\hline $2.5-3.5$ & 17.86 & 11.11 & 3 & 27.59 & 34.09 & 3 & 26.92 & 25.00 \\
\hline $3.5-4.5$ & 10.71 & 16.67 & 4 & 31.03 & 34.09 & 4 & 7.69 & 6.82 \\
\hline 4.5 and above & 21.43 & 41.67 & 5 & 31.03 & 20.45 & 5 & 0 & 11.36 \\
\hline
\end{tabular}

inverted U-trend. Additionally, the higher the income, stronger is the willingness to settle. Finally, physical condition has a marked effect on settlement intention.

\section{Analysis of panel binary choice model for factors affecting rural-urban migrants'settlement intention}

The contingency tables showed that the independent variables - sense of belonging, social identity, age, income, and physical condition-have a significant impact on settlement intention, while the effect of gender and education is not so obvious. The estimated results of the panel binary choice model are shown in Table 5.

Table 5 provides results of the effect on settlement intention. As predicted, sense of belonging has a significant impact on the settlement intentions of rural-urban migrants. With other conditions unchanged, migrant workers' willingness increases with the improvement of their sense of belonging. Social identity has a positive effect on settlement intention. Moreover, rural-urban migrants with higher annual incomes and more education, but with a poorer physical condition, are more likely to settle in cities.

\section{Explanation}

Results of the model indicated that sense of belonging and social identity, the core variables, are positively correlated with settlement intention. Additionally, wage level, physical condition, and educational level-i.e. the control variables-have a remarkable influence on settlement intention. There is no significant correlation between the other variables and the settlement intention of rural-urban migrants.

The sense of belonging of rural-urban migrants has a significant positive influence on their willingness to settle in cities. This sense of belonging is measured by the number of friends whom migrants can receive support from, the number of people with whom they can share their worries with, the number of people with whom they can discuss problems with, the degree of familiarity with others, their degree of trust in others, and the frequency of mutual assistance. If they have more friends to share their worries with, they can obtain more resources to help themselves in city life. This dynamic tends to produce a feeling of warmth and belonging, with residents feeling as though they are a part of the larger city, resulting in a stronger desire for urban settlement.

Rural-urban migrants with a higher social status are also more inclined to settle in cities. Because of the dualistic structure of cities, migrant workers, a disadvantaged group therein, are vulnerable to identity discrimination and are at a disadvantage in terms of living conditions and material life (ZHAO,1999; ZHU et al., 2017). When they received more respect and recognition in their lives and work, their sense of inferiority weakens, their self-esteem strengthens, and thus they are more willing to settle.

The income of rural-urban migrants is positively correlated with their settlement intention. Their main reason for coming to a city in the first place is to earn a higher wage, increase their socioeconomic status, and increase their happiness and 
Table 5 - Analysis of panel binary choice model.

\begin{tabular}{lccc}
\hline Set & Coef. & $\mathrm{z}$ & $\mathrm{P}>|\mathrm{z}|$ \\
\hline w1 & $0.427^{* * *}(0.143)$ & 2.98 & 0.003 \\
w2 & $0.342^{*}(0.186)$ & 1.84 & 0.066 \\
\hline Gender & $0.301(0.239)$ & 1.26 & 0.207 \\
\hline Insurance & $0.032(0.269)$ & 0.12 & 0.905 \\
Fund & $-0.260(0.307)$ & -0.85 & 0.397 \\
Age & $-0.016(0.689)$ & -0.23 & 0.820 \\
Age (2) & $0.000(0.001)$ & 0.25 & 0.800 \\
Wage & $0.068^{*}(0.030)$ & 2.31 & 0.021 \\
\hline Health & $-0.201^{*}(0.122)$ & -1.65 & 0.099 \\
\hline Education & $0.144^{*}(0.086)$ & 1.68 & 0.094 \\
Religion & $0.133(0.277)$ & 0.48 & 0.632 \\
Training & $-0.238(0.221)$ & -1.08 & 0.281 \\
Cons & $-2.108(1.422)$ & -1.48 & 0.138 \\
\hline Wald chi2(12) & 41.18 & & \\
\hline Prob>chi2 & 0.0000 & & \\
\hline
\end{tabular}

Notes: Coef. is short for coefficient; cons is short for constant; ${ }^{*},{ }^{* *},{ }^{* * *}$ indicate significant levels at 10 per cent, 5 per cent, and 1 per cent respectively.

sense of satisfaction. Only when wages can meet the needs of migrant workers are, they likely to settle in cities. High wages provide satisfactory living standards and enrich their material life, further bolstering their willingness to settle.

The better the physical condition of ruralurban migrants, the more likely they are to go back to rural areas. When they feel healthy, the more advanced health care system commonly reported in cities is less attractive and they have a strong sense of their ability to ward off disease and avoid the costs of illnesses, making them less likely to remain in cities.

Migrant workers with higher education levels, conversely, have stronger settlement intentions. Working in cities requires a higher standard of education and more technical skills, while working in rural areas requires lower academic qualifications. When migrants are highly educated, they are more willing to seek employment in cities to obtain greater career development opportunities. Highly educated migrant workers usually have significant experience with urban life, so it is easier for them to integrate into cities.

Gender, basic endowment insurance, and provident housing funds have no significant effect on settlement decisions. Nowadays, Chinese society emphasizes equality between men and women; this means that the economic pressure on women is gradually increasing, resulting in a negligible relationship between settlement intention and gender. In addition, with the popularization of Chinese rural medical insurance, insurance for major diseases in rural areas is becoming better. Compared with cities, the rural environment, with its slow pace of life and natural and simple attitude toward living, has solved the problem of supporting the elderly, to such an extent that basic endowment insurance has little influence on migrant workers ' intention to stay in cities. Moreover, urban housing prices are high and the income of migrants is low. This means that owning a housing provident fund does not necessarily mean that they will have housing in a city, resulting in such funding having a minimal impact on migrants' settlement decisions.

This paper reported that the influence of age on the settlement intentions of rural-urban migrants is not obvious. With the acceleration of social urbanization, migrant workers tend to be younger, with a strong pioneering and adventurous spirit and appetite for risk. The prospect of settling may be viewed as unnecessarily constricting to such workers. However, with the increase of age, migrant workers are confronted with physical limitations, children's education costs, housing, medical issues, and other circumstances, which encourage them to aspire to 
the high level of a city environment. Therefore, the influence of age on their settlement intention changes according to social environment mentalities, with no significant correlation between them.

Religious belief has little influence on the decision of rural-urban migrants to stay in cities. This paper concluded that there are few people with religious beliefs in China. This implies that the majority of migrant workers in the model data do not have religious beliefs, which leads to a less obvious relationship between them.

Professional skills training also has an insignificant impact on the settlement intentions of migrant workers. Some researchers have indicated that peasant laborers in cities are engaged in a lowtechnology context based on human capital; however, due to continuous advancements in social technology, demand for such technological skills are increasing, which means that a single type of training may not suffice to enhance peasant laborers' employment competitiveness. Moreover, the number of ruralurban migrants who have working experience in this research sample is small, making their influence on the model result also small.

\section{CONCLUSIONS AND DISCUSSION}

This paper adopted data from the China Labor-force Dynamics Survey (CLDS), conducted by the Social Science Survey Center of Zhongshan University in 2012 and 2014; it also uses tracking data. The factors influencing rural-urban migrants' settlement intentions were analyzed and estimated. The results suggested that the subjective wellbeing (migrant workers' sense of belonging, social identity) makes an impressive impact on the decision to stay or move, while actual mobility behavior is also influenced by factors like age, income, education, and health status. Examining the difference in data between 2012 and 2014, migrants gradually adapted to city life and their social circles expanded. Moreover, the sense of respect and trust gained from their work gradually increased with the passage of time. It can be seen that their sense of belonging, along with increases in social identity and solidarity, tends to promote an intention to settle. Additionally, due to the fact that the income of migrant workers is far lower than the average urban income level, this gap inevitably generates psychological dissatisfaction with society. This will likely result in difficulties integrating into society, thus hindering their sense of belonging in urban communities. In terms of social security, migrant workers do not enjoy the same treatment as urban residents in matters such as medical treatment and housing, which has negative effects. It can make them feel discriminated against and may result in their having difficulties obtaining a high level of social status, thus reducing their willingness to settle.

Before this study, the research team knew little about the role played by the cognitive aspect on rural-urban migrants' intentions. Thus, the study focused on the role of social identity in shaping their intention to settle in cities. Results demonstrated that social identity influences migrants' intention significantly, and the effect is only slightly less than their sense of belonging (DU \& LI, 2012; FAN, 2011; ZHU \& CHEN, 2010). In other words, the notion that both cognitive (social identity) and affective (sense of belonging) evaluations influence migrants' intention is partially supported by the data, which is also consistent with our hypothesis in the beginning.

Besides, the study concerns the influence of demographic attributes and migration status as well. These background characteristics have been reported to influence mobility intention in the literature on Chinese peasant migrants (DU \& LI, 2012). In line with previous studies, the effects of education and wage levels on migrants' intentions were found to be significantly and positively related. The effect of their physical conditions was rarely analyzed before. Although, the result of this study may not be expected, it is prevalent in the Chinese context. Due to the heterogeneity of the medical guarantee system between rural and urban areas, a higher quality health care system seems to influence positively migrants' intentions. That said, if urban health care systems in cities are either ineffective or too expensive, and rural systems promise better disease prevention and lower costs, migrants are less likely to remain in cities. Another possible explanation for the negative relationship between physical conditions and migrant intentions is that in some cities in northern China, migrants begin to live unhealthily after moving to cities due to industrial pollution. However, the causality between them cannot be confirmed due to limitations in the data.

One knowledge gap is regarding the role that subjective factors (sense of belonging and social identity) play in the intention of migrants or settle in their destination cities, and whether such factors are more or less than important than others, such as demographic attributes and migration status. However, these subjective emotions do not exist in a social vacuum, and can be and oftentimes are shaped by social, economic, political, and cultural 
environments. Thus, to promote urbanization, policy makers are encouraged to consider the following recommendations. First, the government should encourage peasant workers to participate in community activities and interact with locals, expanding their social communication network. Second, the government is encouraged to raise the income of the peasant laborer, increase the minimum wage of cities, and provide subsidies. Third, it is important to increase the employment competitiveness of rural-urban migrants by promoting their human capital and improving the employment environment. Fourth, it is necessary to raise awareness about the plight of peasant workers and encourage enterprises and the community at large to concern themselves with such workers' welfare. This will improve their sense of belonging and accelerate their integration into urban society. Moreover, eliminating institutional discrimination and psycho-socio-discrimination is crucial for improving peasant workers' livelihoods. Expediting hukou reform is also important so that migrants can enjoy urban social security policies, a process that will promote their intention to settle. Fifth, the government is recommended to strengthen the training of rural laborers; this can be done by increasing investment in vocational and technical education, conducting corresponding educational training courses, increasing advanced technical work training guidance, and carrying out periodic training programs to improve the skillsets of rural-urban migrants. Such training will increase their willingness to settle.

Finally, the conclusions of this study are constrained by the sample size and the challenge of controlling for unobserved heterogeneity. Therefore, additional follow-up surveys are needed in the future. The complexity of migrants' sense of belonging and social identity should be further explored through qualitative research. Future research in these areas is encouraged to provide information that could increase migrants' intentions within various scenarios. This would be beneficial for the formulation and implementation of rural-urban migrant policies, and thus improve the quality of urbanization.

\section{ACKNOWLEDGEMENTS}

We would like to thank two anonymous reviewers and the editor of this journal for their useful comments and suggestions. This work was financially supported by the Key Project of Philosophy and Social Science Research in Colleges and Universities in Jiangsu Province (2017ZDIXM098) and the National Natural Science Foundation of China (NSFC: 71603126 and 7181101261).

\section{DECLARATION OF CONFLICT OF INTERESTS}

The authors declare no conflict of interest. The founding sponsors had no role in the design of the study; in the collection, analyses, or interpretation of data; in the writing of the manuscript, and in the decision to publish the results.

\section{AUTHORS' CONTRIBUTIONS}

All authors contributed equally for the conception and writing of the manuscript. All authors critically revised the manuscript and approved of the final version.

\section{REFERENCES}

ASHFORTH, B.E.; MAEL, F.A. Social Identity Theory and Organization. The Academy of Management Review, v.14, n.1, p.20-39, 1989. Available from: <https://doi.org/10.5465/ amr.1989.4278999>. Accessed: Jan. 19, 2018. doi: 10.5465/ AMR.1989.4278999.

BELGIOJOSO, E.B.D. Intentions on desired length of stay among immigrants in Italy. Genus, Amsterdam, v.72, n.1, p.1, 2016. Available from: <https://doi.org/10.1186/s41118-016-0006-y>. Accessed: Jul. 14, 2016. doi: 10.1186/s41118-016-0006-y.

CHISWICK, B.R.; MILLER, P.W. The Endogeneity between Language and Earnings: International Analyses. Journal of Labor Economics, v.13, n.2, p.246-288, 1995. Available from: <https:// www.jstor.org/stable/2535104>. Accessed: Apr. 19, 2018. doi: $10.1016 / \mathrm{S} 0022-474 \mathrm{X}(00) 00016-3$.

CHEN, S.; LIU, Z. What determines the settlement intention of rural migrants in China? Economic incentives versus sociocultural conditions. Habitat International, v.58, p.42-50, 2016. Available from: <https://doi.org/10.1016/j. habitatint.2016.09.004>. Accessed: Nov. 14, 2016. doi: 10.1016/j.habitatint.2016.09.004.

CHEN, W.Z. Changes and internal differentiation of floating population's Settlement intention: Evidence from four cities in Fujian Province. South China Population, v.23, n.2, p.1511-1516, 2008. Available from: $<$ http://en.cnki.com.cn/article_en/cjfdtotallfrk200802011.htm>. Accessed: Feb. 18, 2018. doi: 10.1002/ marc. 200700305 .

CRAMER, P. Identity change in adulthood: The contribution of defense mechanisms and life experiences. Journal of Research in Personality, v.38, n.3, p.280-316, 2004. Available from: <https:// doi.org/10.1016/S0092-6566(03)00070-9>. Accessed: Jun. 15, 2018. doi: 10.1016/S0092-6566(03)00070-9.

DU, H.; LI, S.M. Is It Really Just a Rational Choice? The Contribution of Emotional Attachment to Temporary Migrants' Intention to Stay in the Host City in Guangzhou. The China Review. The China Review, v. 12, n. 1, p.73-94, 2012. Available from: <http://www. jstor.org/stable/23462318>. Accessed: Jun. 20, 2018.

ETTE, A., et al. Tackling Germany's Demographic Skills Shortage: Permanent Settlement Intentions of the Recent Wave of Labour Migrants from Non-European Countries. Journal of International 
Migration and Integration, v.17, n.2, p.429-448, 2015. Available from: <https://doi.org/10.1007/s12134-015-0424-2>. Accessed: Jan. 15, 2018. doi: 10.1007/s12134-015-0424-2.

FAN, C.C. Settlement Intention and Split Households: Findings from a Survey of Migrants in Beijing's Urban Villages. China Review, v.11, n.2, p.11-41, 2011. Available from:_<https://www. jstor.org/stable/23462343>. Accessed: Jun. 18, $201 \overline{8}$.

FLYNN, M.; KAY, R. Migrants' experiences of material and emotional security in rural Scotland: Implications for longerterm settlement. Journal of Rural Studies, v.52, p.56-65, 2017. Available from: <https://doi.org/10.1016/j.jrurstud.2017.03.010> Accessed: May, 15, 2017. doi: 10.1016/j.jrurstud.2017.03.010.

HAO, P.; TANG, S. Floating or settling down: The effect of rural landholdings on the settlement intention of rural migrants in urban China. Environment and Planning A, v.47, n.9, p.289-298, 2015. Available from: <https://doi.org/10.1177/0308518X15597131>. Accessed: Aug. 20, 2018. doi: 10.1177/0308518X15597131.

HUANG, Q. An Analysis on the Factors Affecting the Rural Labor Migrations' Desire to Settle in Cities--An Empirical Analysis Based on the Survey of Five Cities. Journal of Shanxi Finance and Economics University, v.30, n.4, p.21-27, 2008. Available from: $<$ http://en.cnki.com.cn/Article_en/CJFDTOTALSXCJ200804005>. Accessed: Apr. 15, 2018. doi: 10.13781/j .cnki .1007-9556.2008.04.002.

HUANG, X., et al. The efects of social ties on rural-urban migrants' intention to settle in cities in China. Cities, v.83, n.4, p.21-27, 2018 Available from: <https://doi.org/10.1016/j.cities.2018.06.023>. Accessed: Dec. 31, 2018. doi: 10.1016/j.cities.2018.06.023.

SIMMON, A., et al.Social change and internal migration: a review of research findings from Africa, Asia, and Latin America. A report of the Migration Review Task Force. International Development Research Centre, v.4, n.1, p.113-128, 1977. Available from: $<$ https://eurekamag.com/research/000/499/000499092.php $>$. Accessed: Dec. 31, 2018. doi: 10.2307/1972168.

KHOO, S.E. Sponsorship of Relatives for Migration and Immigrant Settlement Intention. International Migration, v.41, n.5, p.177-199, 2004. Available from: <https://doi.org/10. 1111/j.0020-7985.2003.00265.x>. Accessed: Jan. 15, 2018. doi: 10.1111/j.0020-7985.2003.00265.x.

LEE, B.A., et al. Neighborhood Context and Residential Mobility. Demography, v.31, n.2, p.249-270, 1994.Available from: < https:// doi.org/10.2307/2061885>. Accessed: May, 12, 2018. doi: $10.2307 / 2061885$.

LIU, Y., et al. Influence factor analysis of migrants' settlement intention: Considering the characteristic of city. Applied Geography, v.96, p.130-140, 2018. Available from: <https://doi. org/10.1016/j.apgeog.2018.05.014>. Accessed: Jul. 18, 2018. doi: $10.2307 / 2061885$

LIU, Y., et al. Settlement Intention of New Migrants in China's Large Cities: Patterns and Determinants. Scientia Geographica Sinica, v.34, n.7, p.780-787, 2014. Available from: <http:// geoscien.neigae.ac.cn/en/y2014/v34/i7/780>. Accessed: Jul.18, 2018. doi: $10.11821 /$ dlyj201402003.

LIU, Y., et al. The subjective wellbeing of migrants in Guangzhou, China: The impact of the social and physical environment.
Cities, v.60, p.333-342, 2017. Available from: <http://dx.doi. org/10.1016/j.cities.2016.10.008>. Accessed: Feb. 14, 2018. doi: 10.1016/j.cities.2016.10.008.

ROBERT, E.; LUCAS. Life Earnings and Rural-Urban Migration. Journal of Political Economy, v.112, n.1, p.29-59, 2004. Available from: <https://www.jstor.org/stable/10.1086/379942>. Accessed: Feb, 14, 2018. doi:10.1086/379941.

MALANCHUK, O., et al. The Ontogeny of Career Identities in Adolescence. New Directions for Child and Adolescent Development, v.2010, n.130, p.97-110, 2010. Available from: $<$ https://doi.org/10.1002/cd.284>. Accessed: Feb. 14, 2018. doi:10.1002/cd.284

MOHABIR, N., et al. Chinese floating migrants: Ruralurban migrant labourers' intentions to stay or return. Habitat International, v.60, p.101-110, 2017. Available from: $<$ https://doi. org/10.1016/j.habitatint.2016.12.008>. Accessed: Feb. 14, 2018. doi: $10.1016 /$ j.habitatint.2016.12.008.

PALMER, N.A., et al. Social capital and community participation among migrant workers in China. Journal of Community Psychology, v.39, n.1, p.89-105, 2011. Available from: <https:// doi.org/10.1002/jcop.20419>. Accessed: Jan. 12, 2018. doi: $10.1002 /$ jcop. 20419 .

NELSON, J.M. Sojourners versus New Urbanites: Causes and Consequences of Temporary versus Permanent Cityward Migration in Developing Countries. Economic Development and Cultural Change, v. 24, n.4, p.721-757, 1976. Available from: $<$ https://www.jstor.org/stable/1152946>. Accessed: Jul. 18, 2018. doi: $10.1086 / 450916$.

SCHULTZ, T.W. Investment in Human Capital. Economic Journal, v.82, n.326, p.787-788, 1972. Available from: <http:// www.jstor.org/stable/2230051>. Accessed: Jun. 15, 2018. doi: $10.2307 / 2230051$.

SCHWARTZ, S., et al. The Role of Identity in Acculturation among Immigrant People: Theoretical Propositions, Empirical Questions, and Applied Recommendations. Human Development, v.49, n.1, p.1-30, 2006. Available from: <http:// www.jstor.org/stable/2230051>. Accessed: Jun, 20, 2018. doi: $10.1159 / 000090300$.

SHEN, J.; LIU, Y. Skilled and less-skilled interregional migration in China: A comparative analysis of spatial patterns and the decision to migrate in 2000-2005. Habitat International, v.57, p.1-10, 2016. Available from: <https://doi.org/10.1016/j. habitatint.2016.06.007>. Accessed: Oct. 22, 2018. doi: 10.1016/j. habitatint.2016.06.007.

SHIELDS, G.M.; SHIELDS, M.P. The Emergence of Migration Theory and a Suggested New Direction. Journal of Economic Surveys, v.3, n.4, p.277-304, 1989. Available from: $<$ https://doi. org/10.1111/j.1467-6419.1989.tb00072.x>. Accessed: Feb. 14, 2018. doi:10.1111/j.1467-6419.1989.tb00072.x.

STARK, O. Migration,Remittances,and the Family. Economic Development and Cultural Change, v.36, n.3, p.465-481, 1988. Available from: $<$ https://doi.org/10.1086/451670 $>$. Accessed: Apr. 12, 2018. doi: 10.1086/451670.

TANG, S.; FENG, J. Cohort differences in the urban settlement intentions of rural migrants: A case study in Jiangsu Province, 
China. Habitat International, v.49, p.357-365, 2015. Available from: <https://doi.org/10.1016/j.habitatint.2015.06.009>. Accessed: Oct. 22, 2018. doi: 10.1016/j.habitatint.2015.06.009.

TODARO, M.P. A Model of Labour Migration and Urban Unemployment in Less Developed Countries. American Economic Review, v.59, n.1, p.138-148, 1969. Available from: $<$ https://www.jstor.org/stable/1811100>. Accessed: Mar. 15, 2018. doi: 10.1111/j.1467-8624.1997.tb01934.x

WANG, Y.J. Settlement Intention of Rural Migrants in Chinese Cities: Findings from a Twelve-city Migrant Survey. Population Research, v.37, n.4, p.19-32, 2013. Available from: <http:// en.cnki.com.cn/Article en/CJFDTOTAL-RKYZ201304003>. Accessed: Mar. 15, 2018.

WU, X.; ZHANG, Z. Population migration and children's school enrollments in China, 1990-2005. Social Science Research, v.53, p.177-190, 2015. Available from: <https://doi.org/10.1016/j. ssresearch.2015.05.007>. Accessed: Sep. 07, 2018. doi: 10.1016/j. ssresearch.2015.05.007.

XIAO, Y.; DENG, R. The Plight of New Generation Migrant Workers in the Integrating Process into Urban Community. Journal of South China Agricultural University, v.14, n.15, p.36-45, 2015. Available from: < http://en.cnki.com.cn/Article_en/ CJFDTotal-HNNA201501005>. Accessed: Jan. 15, 2018. doi: 10.7671/j.issn.1672-0202.2015.01.005.

YOU, Z., et al. Settlement Intention Characteristics and Determinants in Floating Populations in Chinese Border Cities. Sustainable Cities and Society, v.39, p.476-486, 2018. Available from: <https://doi.org/10.1016/j.scs.2018.02.021>. Accessed: May, 12, 2018. doi: 10.1016/j.scs.2018.02.021.

ZHAI, Q. Subjective Well-Being Of China's Off-Farm Migrants. Journal of Happiness Studies, v.11, n.3, p.315-333, 2009 Available from: <http://link.springer.com/article/10.1007\%2
Fs10902-009-9142-9>. Accessed: May, 12, 2018. doi: 10.1007/ s10902-009-9142-9.

ZHANG, B., et al. Does ethnic identity influence migrants' settlement intentions? Evidence from three cities in Gansu Province, Northwest China. Habitat International, v.69, p.94-103, 2017. Available from: <https://doi.org/10.1016/j. habitatint.2017.09.003>. Accessed: Jan.. 12 2018. doi: 10.1016/j. habitatint.2017.09.003.

ZHANG, X.Q. Effects of Social Support on the Migrant Workers' Willingness of Staying in the City--Based on Mediating Effect of Subjective Well-being. Taiwan Agricultural Research, v.5, p.5560, 2017. Available from: <http://www.en.cnki.com.cn/Articleen/ CJFDTOTAL-TWNT201705012>. Accessed: May, 12, 2018. doi: 10.16006/j.cnki.twnt.2017.05.010.

ZHAO, Y. Leaving the countryside:rural-to-urban migration decisions in China. American Economic Review, v.89, n.2, p.281-286, 1999. Available from: <https://www.aeaweb.org/ articles?id=10.1257/aer.89.2.281>. Accessed: May, 11, 2018. doi:10.1257/aer.89.2.281

ZHU, Y. China's floating population and their settlement intention in the cities: Beyond the Hukou reform. Habitat International, v.31, n.1, p.65-76, 2007. Available from: $<$ https://doi.org/10.1016/j. habitatint.2006.04.002>. Accessed: May, 15, 2018. doi: 10.1016/j. habitatint.2006.04.002.

ZHU, Y.; CHEN, W. The settlement intention of China's floating population in the cities: recent changes and multifaceted individuallevel determinants. Population Space and Place, v.16, n.4, p.253267, 2010. Available from: <https://doi.org/10.1002/psp.544>. Accessed: Mar. 12, 2018. doi:10.1002/psp.544.

ZHU, Y., et al. Association between migrant worker experience, limitations on insurance coverage, and hospitalization for schizophrenia in Hunan Province, China. Schizophrenia Research, v.197, p.93-97, 2010. Available from: <https://doi. org/10.1016/j.schres.2017.11.026>. Accessed: Jul. 18, 2018. doi: 10.1016/j.schres.2017.11.026. 